\title{
Universiteit
}

Leiden

The Netherlands

\section{Patterns of attachment in frequently and infrequently reading mother-child dyads}

Bus, A.G.; IJzendoorn, M.H. van

\section{Citation}

Bus, A. G., \& IJzendoorn, M. H. van. (1992). Patterns of attachment in frequently and infrequently reading mother-child dyads. The Journal Of Genetic Psychology, 153(4), 395-403. Retrieved from https://hdl.handle.net/1887/1452

Version: Not Applicable (or Unknown)

License: Leiden University Non-exclusive license

Downloaded from: $\quad$ https://hdl.handle.net/1887/1452

Note: To cite this publication please use the final published version (if applicable). 


\title{
Patterns of Attachment in Frequently and Infrequently Reading Mother-Child Dyads
}

\author{
ADRIANA G BUS \\ MARINUS H VAN IJ $/$ TNDOORN \\ Center for Child and Famuly Studies \\ Leiden Unversitv, The Netherlands
}

ABS TRACT Ihis study explored the clationshup between the quality of the mothet child attachment and how often mothess read to their childien Lighteen childien who were tead to infrequently were matched to a group of children who weie tead to dally for sex, age, and socioeconome status the childien's mothers read them a booklet mother and child were observed in a teunion epsode the childien com pleted the Peabody Picture Vocabulaty Iest (Dunn, 1965) and Fiostig s (1966) test for spatial orientation, and the mothes were given the Adult Altachment interview (George, Kaplan, \& Mam, 1984) The mothes in the frequently reading dyads did not need to discipline their child to focus on the reading task as olten as the mothers in the intrequently reading dyads did Mothers whose attachment to their child was less secure spent less time reading to their child and had more troublesome episodes duting the reading session than mothers whose attachment to thear chald was more secure Ihe secuity of the mother-child attachment was related to the mothes representation of their relationship with their parents, and mothess who had a secure relationship with their child read more trequently to their child than did mothers who had an insecure iclationship with thear child

PARENTS DIFFER GREATLY in the amount of time they iedd to their (hildren dunng their fust 3 years (Teale, 1986) Some childien are not read to at all, whereas other childien have been tead to more than 1,000 hi by the time they enter elementary school (Adams, 1990) The teasons for and the consequences of this tremendous difference in reading experience have not been studied extensively, but at least part of the difference can be attributed to the complexities of teading to a child who does not understand witten language (Bus, 1990) Storybook reading has been regaded as a social interaction (Sulfby \& Teale, 1987) When reading to then child, patents cannot simply 
read the text aloud (Pelligrmi Brody, \& Sigel, 1985), childen will understand a story only if then patents use highly interative language, pallicularly when the book is new to the child Some parents are less awate than others of their child's intentrons and knowledge (Bus \& Sulsby, 1990) Some parents cannot tocus their child's attention on a story, the childen do not show any real interest in the book and tiy to disturb the reading session by making norses playng with toys, ol iunning awdy

Based on attachment theory (Ainsworth. Blehar, Waters, \& Wall, 1978. Bowlby 1969) we hypothesi/ed that mothers in insecurely attached dyads would be less able to focus thell child's attention on a teading task and less able to explan the context and the content of a story Insecure childen have kess lius in then caregives and in themselves and ate less tesllent, that is, less able to cope with difficulties, than securely attached childien ale (Matas. Arend de Sroule 1978, van IJ/endeorn, van der Veer, \& van Vliet Visser. 1987) In previous studies, we tound that msecute childien were less inclined to explore witten language (Bus \& van IJendeom, 1988a) and that me curely atlahed mother-child dyads experienced more troublesome eprsodes when reading than securely attahed lyads did (Bus \& van II/endoonn 1988b) In this study we funther explosed the iclation between frequency of cading number of toublesome epesodes dumg readme, and quality of the mother-chld attachent Because the qually of the mothe-child atlachment seems to be related to the number of noublesome eprodes dumg reading sessions, we hypotheswed that children who are intrequently sead to ate in securely attahed to therr mothers mote olten than die chrlden who are trequently read to Securely attached dyads are chatactered by open communication (Giossmann \& Giossmann, 1990) Mam. 1990) and may theretore deal mote satustatonly with frustratroms that atse when the child is intro duced to witten langlage

Man and her coworkets suggested that the quality of the patent-child attachment may be stongly related to the patents' own experience of attach ment (Main 1990), Mann \& Hesse 1990), Mann, Kaplan, \& Cassidy, 1985) Parents cognttive septesentation, or state of mind, with tespect to then attachment expenences with thea parents determmes how they will ielate to then chiden allectrvely becure patents those who have a secue ieptesen

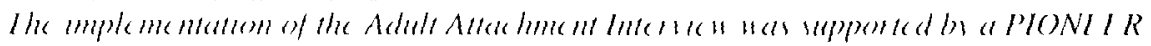

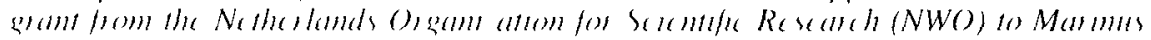

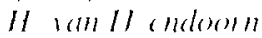

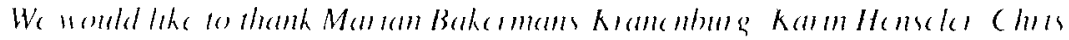

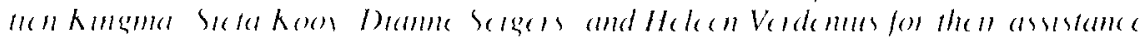

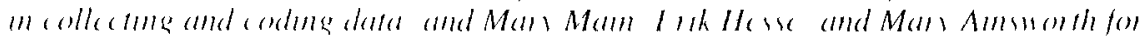
trammethe asder)

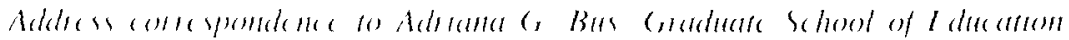

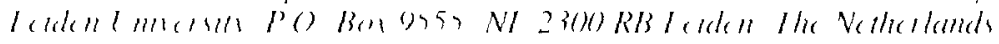


tation of attachment) tolerate mote averse stimuli from their children than do insecure parents because they do not feel threatened by their children's anxi ety or trustration (Main \& Goldwyn in press) In contrast, insecure parents may become insensitive to their children's needs and signals when they are teminded of their own panful attachment experiences Crowell and Feldman (1988) lound that secure mothes support their toddlers more adequately dur ing a problem solving task than insecure mothers do

We hypotheswed that more insecuie mothers than secure mothers would read infiequently to their children and that more secure mothers than insecure mothers would read frequently to their childien Our rationale was that, be cause secure mothers handle troublesome interactions that dise during reading sessions with their children mole adequately than insecure mothers do secure mothes should derive more satisfaction trom reading to their children and should feel more motivated than insecure mothers would to read to then children

Our study was carried out in the laboratory, in contrast to most studies on teding to children, which have been catted out in a natural setting (Sul/by \& Teale, 1987) We pertormed our reseatch in a more structured setting to control for the content of the redding material and the context of the teding session

\section{Method}

\section{Procedure}

We used a questionnare to select 36 mother-child dyads We invited all the dyads to our laboratory and observed a reading session and a reunton of mother and child atter a separation First the mothers iedd to their children We told the mothers to act as they did at home The ieading sessions wete videotaped Then, while the childien were sepalied from thei mothers, they completed (among other tests) the Peabody Picture Vocabulary Test (Dumn 1965) and a test for spatial orientation (Frostig, 1966) The separation lasted lot at least halt an hour We visited the mothers at home to admunster the Adult Attachment Interview (Geotge, Kaplan \& Maın, 1984)

\section{Subleck}

We administered a questronnalte to about 300 mothers when they brought theit child to a playgroup To prevent the mothes from feeling that reading intrequently to their childien was undestadble, we asked whether they had allead begun to tead to then children (Sulzby, personal communication) it the answer was affirmative the mothers were to indicate how many tumes a week they read to then chiklen Twenty one mothers voluntected that the 
read to their childien twice a week or less So that the mothers would not guess the god of the questionnatie, we asked foun other questions about then childien s play behavion We also asked about the children 's age and sex and the parents' occupation and educational level Eighteen of the 21 mothers whoread at most twice a week to their child agreed to paiticipate in the study Their childien were matched to children who were read to daly, for socioeconomic status, age and sex Two pars of chaldten could not be matched on sex

\section{Inomblesome lmtactions}

The mothes read a booklet to ther childen that included all the relevant aspects of a story (setting, intlating event, internal response, internal plan, attempt, duect consequence, and reation) (Stem \& Glenn, 1979) The booklet was 10 pages long and contaned text and an allustiation on every page Using the videotape of the reading sessions, we coded the number of eprsodes in which the mothers tued to focus then child's attention on the booklet atter the child verbally ot nonverbally demonstlated that he or she had no interest in the booklet on wished to do something else I hese troublesome episodes sometmes contaned mote than one rematk Agreement between two independent coders was $85(N$ 8)

\section{Mothe'-C Inld Aluch hme'nt}

I ollowing the procedute of Man, Kaplan, and Cassidy (1985, p 80 ) 17 ), we sepaded the childen once for about hall an hout from then mothers, and recorded thesr ieunion on videotape We tated the children s behavior dung the first 5 mon of the ieunton, using a levised version of a 9-point secunty rade tor 6 year olds (Man et al) The revised scale meluded more extensive descruptions of mecure behavior and emphasised the kinds of behavion that are typical of younger childen the intercoder relability of two independent coters uas $86(N \quad$ 15) Ihe application of a similat scale for the same age group was rehable and valud in previous reseatch, the securly sale showed convergent validity in cortelating strongly $(1-75)$ with a combination of frequency scores for positive aftective behavios (such as smiling. looking. showing. and acceptang) and also appealed to have predicuve validity the atmosphere surrounding the mteration of securely attached dyads appeared to be more postlive than that surounding the intetation of the insecurely attached dyads Also, as expected, the mothers of secutely attached childien wete able to stumulate theri childen to function at a highes level when teading (Bus \& van IJ/endoon, 1988b) 


\section{Ihe Adult Attac hme nt Intenien}

We medsured maternal state of mind with respect to attachment, using the Adult Attachment Interview (AAI, George et al , 1984) The AAI 1s a semı structured interview designed to elicit descriptions of a person's childhood relationship with his or hei parents, specific supportive memories, and de scriptions of a person's current relationship with his or her parents The interview was recorded on dudiotape and transcribed verbatım The transcribed interviews were classified according to the security of the current parent-child attachment Coding of the AAI according to the Main and Goldwyn coding system resulted in four attachment categories securelautonomous (F) dis mussue (D), preoccupled (E), and uniesolved uith respect to thauma (U) Interviews that were classined $U$ were reclassined in the next closest of the three temainıng categories (Main \& Goldwyn, in press)

In this article we will discuss only insecure ( $D$ and $E$ ) versus secure di chotomy because our sample size was relatively small and because we did not make specific hypotheses about the dismissive and preoccupied groups, expectıng that both these groups would deal less adequately than secure mothers would with troublesome episodes that alose when they iead to therr childien The uniesolved status is a transitory stage that periodically accompanies one of the man strategies (D, E, or F) of dealing with attachment relationships (van IIzendootn, 1992)

Because some subjects refused to participate and because of technical fallure, there were 33 tianscupts avalable for coding Eleven mothers were coded as dismissively attached, 14 mothers as securely attached, and 8 moth crs as pieoccupied This distribution reflected an overrepresentation of insecurely attached mothes (58\%) compared with the distribution of insecurely attached mothers in middle-class samples ( $52 \%$, see van IJzendootn, 1992) The second author coded the tianscripts without any knowledge about the childien's characteristics, how often they were icad to, or then interactions with their mother Alter traning, intercoder agreement redched $82 \%$ on 22 Fnglish transciupts and $90 \%$ on 10 Dutch tiansciets

\section{Statrstual Anahw}

We compared the two groups of childien using $t$ tests for matched pars The tests were one talled becaluse we had explicit expectations about the disection of the effects All the andyses were perlormed twice-once with all the parts and once without the two palls that were not matched for sex The results of the latter set of analyses did not differ from those of the former set and there tote will not be seported The contelations between continuous variables were established with Pearson product-moment conelation coefficients 


\section{Results}

First, we examined the differences between the background variables for the frequently reading dyads and the intrequently reading dyads. The children's mean age was 3.4 years (see Table 1), and the subjects were from families of low socioeconomic status (van Westerlaak, Kropman, \& Collaris, 1975). The only difference between the two groups was frequency of reading.

Second, we examined the number of troublesome episodes, the security of the mother-child attachment, and the mother's representation of her attachment experience, for each group. The number of troublesome episodes for the frequently reading dyads was significantly lower than that for the infrequently reading dyads, $f(17)=3.54, p<.002$. The mean numbers of troublesome epsodes were $7(S D=1.0)$, and $2.4(S D=1.8)$, for frequently reading dyads and infrequently reading dyads, respectively.

The security of the mother-child attachment for five dyads could not be assessed because the children refused to be separated from thew mothers. Four out of five of these children belonged to infrequently reading dyads. The mean security of the children who were read to intrequently was significantly lower $(M=41, S D=1.2)$ than that of the children who were read to daily $(M=6 .(), 5 D-1.7)$. InI requently reading dyads were less securely attached

TABISI

Characteristics of ('hildren in Infrequently and Frequently Reading Dyads

\begin{tabular}{|c|c|c|c|c|c|}
\hline \multirow{2}{*}{$\begin{array}{l}\text { Backgnomal } \\
\text { vanables }\end{array}$} & \multicolumn{2}{|c|}{$\begin{array}{l}\text { Intrequently } \\
\text { icading dyads }\end{array}$} & \multicolumn{2}{|c|}{$\begin{array}{l}\text { requently } \\
\text { reading dyads }\end{array}$} & \multirow[b]{2}{*}{1} \\
\hline & $M$ & $S I)$ & $M$ & $S I)$ & \\
\hline Frequency of reading (per week) & 17 & 8 & 48 & 7 & $1223 r$ \\
\hline $\begin{array}{l}\text { Age (in months) } \\
\text { SES }\end{array}$ & 397 & 58 & $40) 1$ & 55 & 10() \\
\hline $\begin{array}{c}\text { (maximum seore - 6) } \\
\text { Peabody Picture Vocabulary }\end{array}$ & 22 & 11 & 24 & 8 & 67 \\
\hline $\begin{array}{l}\text { Test } \\
\text { Spatial orientation test }\end{array}$ & 986 & 180 & 950 & 208 & 69 \\
\hline $\begin{array}{l}\text { (maximum seore } \\
\text { Buth order }\end{array}$ & $\begin{array}{l}35 \\
16\end{array}$ & $\begin{array}{r}13 \\
5\end{array}$ & $\begin{array}{l}30 \\
22\end{array}$ & $\begin{array}{l}10 \\
13\end{array}$ & $\begin{array}{l}107 \\
157\end{array}$ \\
\hline
\end{tabular}

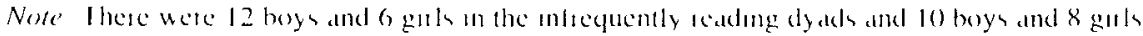

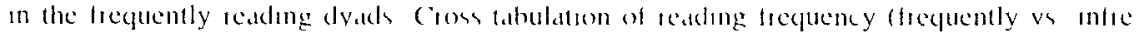

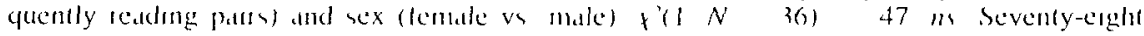

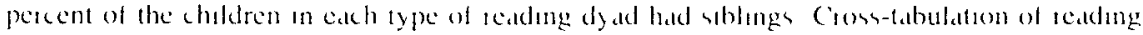

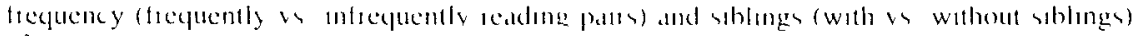
$11, N$ 3(1) $(10, \mathrm{~m}$

${ }^{+} P(0) 1$ 
than frequently reading dyads were, $t(12)=3.67, p<.002$, and the less secure dyads experienced more troublesome episodes during the reading session than the more secure dyads did, $r(31)=-.43, p<.009$.

The security of the mother-child attachment was strongly related to the security of the mother's representation of previous attachment experiences $r(32)=.52, p<.002$. There were more insecure mothers in infrequently reading dyads than in frequently reading dyads, $75 \%$ and $41 \%$, respectively, $X^{2}(1, N=33)=3.86, p<.05$. Insecure mothers provoked more troublesome episodes than secure mothers did, $r(33)=-.30, p<.05$.

\section{Discussion and Conclusions}

One purpose of this study was to describe the differences between frequently and infrequently reading dyads. The atmosphere of the reading interaction seemed better in frequently reading dyads than in infrequently reading dyads; in frequently reading dyads, there appeared to be less need to discipline the child to focus on the reading task. This may explain why the mothers in the infrequently reading dyads did not read often to their child, assuming that a greater number of troublesome episodes lessens the pleasure of reading. However, we cannot ignore the possibility that reading may have been more troublesome for the infrequently reading dyads because they were not used to reading at home.

To investigate the difference in reading frequency, we explored the relation between attachment and frequency of reading. Attachment and reading were related in several different ways. Frequently reading dyads appeared to be more securely attached than infrequently reading dyads. Furthermore, the security of the mother-child attachment was related to the number of troublesome episodes during reading sessions; the more secure a dyad was, the fewer troublesome cpisodes it experienced. This result confirms an earlier finding that secure children are easier to instruct during reading sessions (Bus \& van IJzendoorn, 1988b). Some might interpret this finding as a suggestion that children become more securely attached to their parents as a result of frequent, successful contact that involves reading. To us, it seems more plausible that a secure attachment relationship results in a better affective atmosphere during a relatively difficult task (such as reading to a child and introducing the child to written language) and that this more favorable atmosphere may stimulate mothers to read more often to their child.

The findings that frequently reading mothers are more secure than infrequently reading mothers and that secure mothers do not provoke as many troublesome episodes during reading sessions as insecure mothers do further support this hypothesis and suggest that the quality of the interaction during reading sessions is closely related to the mother's attachment experiences. Secure mothers are more aware of their child's signals of anxiety and frustrat- 
tion and better able to respond flexibly to the challenges of intioducing then child to d new subject (Crowell \& Feldman, 1988) The lact that the peicentage of secure mothers in this sample was iclatively low (42\%) may be related to the low sociocconomic status of the participating lamilies Previous studies that used maddle class samples did have a somewhat higher percentage (48\%) of secure adult attachment (van IJendoom, 1992)

Two of out findings were especially important Fist, the affective relationship between mothet and child may be important for instruction and cognitive development Mothers are less able to mstruct the child when the attachment relationship is less secure, and they spend less tume reading to their childien Second, the results of our study supported the theory that the mateinal iepresentation of attachment is related to the quality of the motherchild attachment and that a secure maternal tepresentation of attachment may be a preiegusite it a mother is to adequately assist her child in the exploration of witten language

\section{RH F ERENC IS}

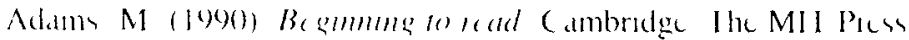

Amsuserth M D) S Blchan M C Watus i \& Wall S (1978) Pattams of attar hment llalladale NI f ibdum

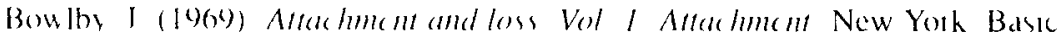

Bus A G (1990) I aly uading acqurstion in P Reitsma \& I Verhocven (Lds) Reading acquastum in Duth A sate of the ant (pp) 15 28) Dordrecht The Netholands 1 ors

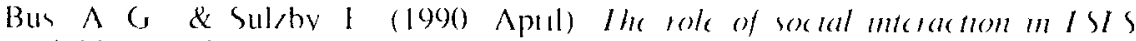

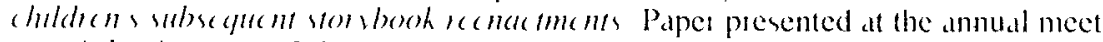
ing of the Americ an I ducational Research Association Boston

Bus A,$\quad \&$ ban IJendoon M H (1988, Attachment and early reading A

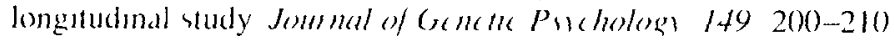

Bus A ( \& \& val IJendoon M H (1988b) Mother-child interdetion attach ment and emergent literay $A$ cross sectional study (hld Derelopmert 59 $1262-1272$

Crowell I A \& I cldmun S S (1988) Mothers intemal models of telationships and children s behavioral and developmental status $A$ sudy of mothet-chikl in icractions (hild Dociclopmont 59 1273-1285

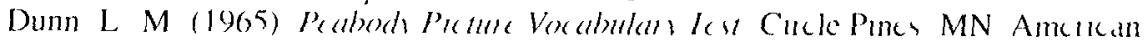
Gurdance Servace

loostag M (1960) Daclapmental lest of Visual Perceprom Palo Alto CA Con sulting Paychologists Picses

George ( Kaplan N \& Man M (1984) Adult Attallment Imtcracu Unpub lished manuscupt Unvesuty of Californat Betkeley

Grossmann K I \& (nossmann K (1990) Ihe wider concept of attahment in

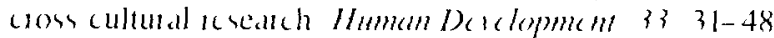

Man M (1990) ( and the concept of condutional statcgee Hemam Do velopment 33 48-62

Man M \& Hose 1 (1990) the patents of mecule desolgamed/disonented 
Intants Obseivations and speculations In M Greenberg, D Cichett, \& M Cum mings (Eds), Attachment in the pre-school rears (pp 161-184) Chicago Unı versity of Chicago Press

Maın, M \& \& Goldwyn, R (in press) Interview-based adult attachment classifica tions Related to infant-mother and infant-tather attachment Deielopmental $P_{4}$ (holog)

Maın, M . Kaplan, N, \& Cassidy, J (1985) Security in intancy, childhood, and adulthood $A$ move to the level of representation In I Bretherton \& $E$ Wates (Eds), Giowing points of attachment theory and research Monograph of the Socien fol Re search in Child Development $50(1-1$, Serial No 209)

Matas L Arend, E A, \& Sroute, L A (1978) Continuity of adaptation in the second year The telationship between quality of attachment and later competence Chuld Deiclopment 49 547-556

Pelligrim, A D. Brody G H, \& Sigel, I E (1985) Parents book leading habits with then childien Journal of Educational Psichologi 77 332-340

Stein N L, \& Glenn, C G (1979) An analysis of story comprehension in ele mentaty school childien $\ln \mathrm{R} O$ Feedle (Ed) Neu direcroms ind disours mo cosime Vol 2 Norwood. NJ Ablex

Sulsby E, \& Teale, W H (1987) Young chuldrens stombooh readme Iongunde

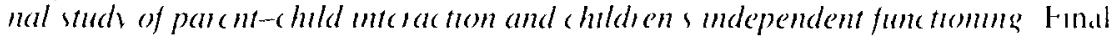
1eport to the Spencer Foundation Ann Arbor The Univessity of Michigan

Feale, W H (1986) Home background and young children s literacy development In W H Teale \& L Sulzby (Eds) I magent lualac) (pp 173-206) Norwood NJ Ablcx

Van IJ/endoorn M H (1992) Intergenerational transmission ol patenting A review of studies in non-clinical populations Deielopmental Revew $12 \quad 76-99$

van IJ/endoorn M H, van der Veer, R \& van Vliet-Visser, S (1987) Attachment three years later Relationships between qualıty of mother-inlant attahment and cognitive development in kindergarten in $\mathrm{L}$ W $\mathrm{C}$ Tavechios \& $\mathrm{M} \mathrm{H}$ van IJzendoorn (Eds), Attachment in social networks Commibutioms to Boul b)-Ainsuorth attachment than (pp 185-225) Amsterdam Ihe Netherlands Elsevier

van Westerlack J M, Kiopman, J A \& Collats J W M (1975) Beroepenh lapper |Occupational index] Nijmegen, I he Netherlands IIs 